\title{
Salt supplementation of dairy cows
}

\author{
M.B. O'CONNOR ${ }^{1}$, M.F. HAWKE ${ }^{2}$, J.E. WALLER ${ }^{1}$, J.R. ROTHERHAM ${ }^{3}$ and S.P. COULTER ${ }^{4}$ \\ ${ }^{1}$ AgResearch, Ruakura, PrivateBag 3123 Hamilton \\ ${ }^{2}$ AgResearch, Private Bag 3020 Rotorua \\ ${ }^{3}$ Waikite Valley Road, RD1 Rotorua \\ ${ }^{4}$ Dominion Salt Ltd, Private Bag 4249 Mt. Maunganui South \\ ${ }^{1}$ oconnorm@agresearch.cri.nz
}

\begin{abstract}
Supplementation of salt to dairy cows on a pumice soil at Waikite, Rotorua gave a $12.8 \%$ increase in milk yield with unaltered composition. The response was immediate and occurred over a 3month trial period. The result was obtained on ryegrass/clover pastures averaging $0.05 \% \mathrm{Na}$ whereas the recommended concentration for dairy cows is $0.12 \% \mathrm{Na}$. Two methods of diagnosing $\mathrm{Na}$ deficiency were examined in the trial namely saliva $\mathrm{Na}$ : K ratios and pasture $\mathrm{Na}$ content. In the case of the former, practical sampling problems and a lack of a production response calibration indicates that of the two methods, pasture analysis will probably be the most simple and reliable means of diagnosing deficiency. Salt supplementation in a $\mathrm{Na}$-deficient situation is likely to be economically very viable. If the $12.8 \%$ milk production response in the current trial was extended to the full lactation period this would give an additional income of $\$ 129 /$ cow (at $\$ 3.50 / \mathrm{kg}$ milk solids) at a cost of $\$ 2.84 /$ cow increased. Sodium deficiency is likely to become more prevalent in the future as outputs of $\mathrm{Na}$ on farms exceed inputs and potassium fertiliser continues to be applied at rates in excess of maintenance. Further work is required to determine critical $\mathrm{Na}$ levels for production responses, the best methods of supplementation, the rates of application required and how well salt dissolves and mixes with other drenches.
\end{abstract}

Keywords: dairy cows, milk yield, salt supplementation, sodium response

\section{Introduction}

Sodium (Na) is an essential element for animals but is not required by plants. Sodium functions in maintaining osmotic balance, in cellular uptake of glucose and in amino acid transport (National Research Council 1989).
Dairy cows routinely expel $\mathrm{Na}$ from the body in urine, faeces, saliva and milk and it needs to be replaced. Inland soils in New Zealand tend to be low in Na. This includes the Central Plateau pumice soils of the North Island and the associated volcanic soils of the Waikato/ King Country and soils of inland Marlborough, Canterbury, Otago and Southland in the South Island. Sodium levels are likely to be declining even further under intensive dairying. Recent results (Rajendram 1998) suggest leaching rates of $\mathrm{Na}$ from soils on dairy farms in the Waikato and Southland range from 30$80 \mathrm{~kg} / \mathrm{ha} /$ annum whereas inputs from rainfall are around $30 \mathrm{~kg} / \mathrm{ha} / \mathrm{annum}$. Also, the continued use of high rates of potassium fertiliser is tending to lower $\mathrm{Na}$ status of pastures (Morton et al. 2000). Excellent milk production responses to salt supplementation of animals grazing lucerne have been obtained (Joyce \& Brunswick 1975) but there has been little work done on dairy cows grazing ryegrass-clover pastures. It was felt important to determine whether dairy cows grazing pastures deficient in $\mathrm{Na}$ would, when supplemented with salt, give increased milk production.

\section{Methods}

\section{Site and trial details}

The dairy farm of J.R. and B.J. Rotherham, Waikite Valley, Rotorua was chosen for the trial. The farm was on predominantly Atiamuri sandy silt, a yellow-brown pumice soil, with an initial soil $\mathrm{Na}$ test of $4 *$ and a pasture $\mathrm{Na}$ analysis of $0.02 \%$. Later pasture sampling gave values of $0.05 \% \mathrm{Na}$. Both levels are low as the recommended pasture level for dairy cows is $0.12 \% \mathrm{Na}$ (Towers \& Smith 1983).

Ninety cows from the farm herd were grouped into 45 pairs based on breed, age, calving date and previous milk production. The two animals in any pair were then randomly allocated to two treatment groups. One group received a daily drench of $14 \mathrm{~g} \mathrm{Na} / \mathrm{cow}$ ( $35 \mathrm{~g} \mathrm{NaCl}$ or common salt) while the other group remained as an undrenched control. Trial cows were run together with

\footnotetext{
* Soil test as used by the AgResearch Soil Fertility Service (G. Rajendram pers. comm.). A $4.4 \mathrm{ml}$ scoop of soil is extracted with $20 \mathrm{ml} 1 \mathrm{M}$ ammonium acetate and the extract read on a 4-channel flame spectrometer. A test of 4 is equivalent to $20 \mu \mathrm{g} / \mathrm{g}$ soil or $0.09 \mathrm{me} / 100 \mathrm{~g}$ soil.
} 
the farmer's herd which received a daily drench of $7 \mathrm{~g}$ $\mathrm{Na} / \mathrm{cow}$. Salt was withheld from the animals for a period of 3 weeks before the start of the experiment and results from a pre-trial herd test were used as a covariate. Trial data were analysed using the analyses of variance routine of Genstat 5 Release 4.1.

The trial commenced on 11 November 1999 and was completed on 17 February 2000.

\section{Measurements}

Fortnightly milk production measurements, together with fat and protein analyses, were undertaken using Livestock Improvement Corporation herd testing services. Somatic cell counts were also recorded.

Saliva samples were taken, in triplicate, from 10 randomly chosen animals from each group in early February 2000. These were analysed for $\mathrm{Na}$ and $\mathrm{K}$.

All animals were weighed at the completion of the trial.

Five monitor paddocks were pasture sampled monthly (by bulking 15-20 hand-clipped samples/ paddock) and analysed for Na. A sample for herbage dissection was taken in February 2000.

The farm stock water supply was analysed for $\mathrm{Na}$ content in December1999.

\section{Results}

\section{Milk yields}

There was a significant milk yield response over the trial period of $12.8 \%$ but no effect on milkfat or protein concentrations (Figures 1 and 2 ).

Milk yield responses occurred within 2 weeks of commencing salt drenching and continued for the duration of the trial. There were no significant differences measured in somatic cell counts between treatments (data not presented).

\section{Herbage sodium concentrations}

Sodium concentrations ( $\% \mathrm{Na}$ ) were consistent and low over the period of the trial within the paddocks sampled, which represented the geographical and soil type range of the farm (Table 1).

\section{Herbage species composition}

The mean herbage composition across five paddocks in February 2000 was $73 \%$ ryegrass, 9\% other grasses, $10 \%$ white clover and $8 \%$ weeds. This composition would have been typical of pastures on farms in the district at that time.

\section{Saliva Na:K ratios}

There was a marked difference in cow saliva Na:K between treatments. Cows being supplemented with
Figure 1 The effect of salt supplementation on milk yield.

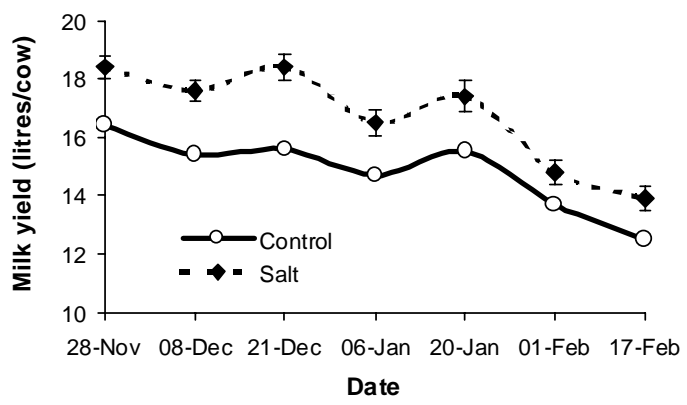

Figure 2 The effect of salt supplementation on milkfat and protein content.

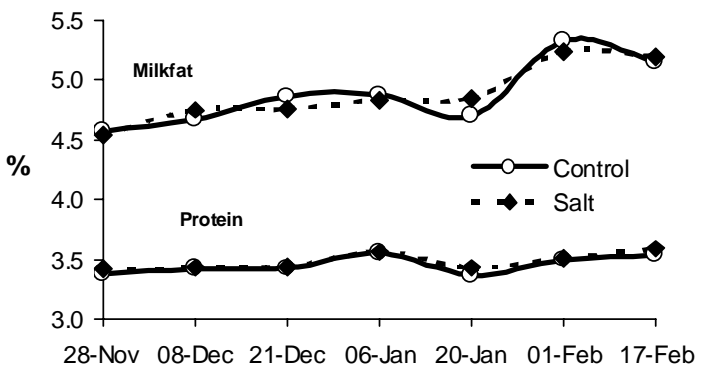

Date

Table1 Sodium concentrations in herbage ( $\%$ DM) on a Waikite, Rotorua dairy farm.

\begin{tabular}{lcccccc}
\hline Date & - & - & & \multicolumn{7}{c}{ Na $(\% D M)$} & & \\
Paddock & 4 & 8 & 24 & 30 & 32 & Mean \\
\hline $4 / 10 / 99$ & - & 0.02 & 0.02 & & & 0.02 \\
$12 / 11 / 99$ & $\overline{-}$ & 0.03 & $\overline{0}$ & 0.06 & 0.04 & 0.04 \\
$9 / 12 / 99$ & 0.04 & $\overline{0}$ & 0.04 & 0.06 & 0.04 & 0.05 \\
$7 / 01 / 00$ & 0.04 & 0.04 & 0.04 & 0.07 & 0.03 & 0.05 \\
$2 / 02 / 00$ & 0.03 & 0.05 & 0.04 & 0.06 & 0.03 & 0.05 \\
\hline
\end{tabular}

salt had significantly greater $\mathrm{Na}: \mathrm{K}$ ratios in saliva compared to unsupplemented cows (16.8 versus 6.7 respectively, LSD 5.8).

\section{Cow liveweights}

There was no difference in the liveweights of the treatment groups over the duration of the trial. The final average liveweight of the supplemented group was $476 \mathrm{~kg}$ compared with $471 \mathrm{~kg}$ for the unsupplemented animals (LSD $10 \mathrm{~kg}$ ).

\section{Discussion}

\section{Milk yield responses}

A $12.8 \%$ response in milk yield to supplementation with salt was achieved in this trial. This was a similar result to that obtained by Joyce \& Brunswick (1975) in 
a salt supplementation trial at Reporoa on lucerne dominant pasture (12\% response) although that trial had to be discontinued after 3 weeks when the control herd was drenched with salt.

Milk yield responses occurred within 2 weeks of supplementation and continued throughout the trial period with a slight fall off in the last two samplings as overall milk yields declined (Figure 1). This suggests that salt supplementation would need to be continued throughout the lactation period.

\section{Effects on fat and protein content}

There was no evidence from the trial that fat or protein concentration was affected following salt supplementation (Figure 2). Joyce \& Brunswick (1975) also noted no change in $\%$ fat (protein not measured) in the Reporoa trial. Overseas data (Chiy \& Phillips 1991) have suggested an increase in fat content (but not protein) when animals were fed both a pasture and concentrate diet supplemented with salt. In other work, quoted by the same authors, increases in lactose content were also noted. Lactose content was not measured in the current trial.

\section{Methods of diagnosing Na deficiency}

It will be important to determine whether $\mathrm{Na}$ will be required or not on a particular dairy farm. Two methods of diagnosis were incorporated into the current trial.

\section{Saliva Na:K ratios}

There was a significant $(\mathrm{P}<0.05)$ difference in saliva $\mathrm{Na}: \mathrm{K}$ between the two treatment groups. This suggests saliva sampling (and $\mathrm{Na}: \mathrm{K}$ ratio in the saliva) could be a useful method of diagnosing $\mathrm{Na}$ deficiency supporting the previous work of Towers (1983). Some variability occurred between animals in both the treated and untreated groups in the current study indicating that up to 10 animals might need to be tested. Unfortunately, the test is difficult to undertake for anyone other than a veterinarian with the correct equipment (mouth brace) and prepared sponges used to collect the parotid saliva. Overseas data (quoted by Chiy \& Phillips 1995) suggested $\mathrm{Na}: \mathrm{K}$ ratios $>10$ indicate $\mathrm{Na}$ sufficiency while less than 2.3 indicated Na deficiency. More work would be required to calibrate the test for $\mathrm{NZ}$ conditions as the current trial results would indicate salt responses were obtained where the $\mathrm{Na}: \mathrm{K}$ ratio averaged 6.7. At this stage it would appear that saliva testing is not a very practical method for the farmer to adopt and that the test requires further calibration with milk production.

\section{Sodium content of pastures}

The pasture $\mathrm{Na}$ status averaged $0.05 \% \mathrm{DM}$ over the trial period (Table 1). Values were consistently lower than the recommended $0.12 \% \mathrm{Na}$ for lactating dairy cows (Towers \& Smith 1983). There appeared to be little variation over the trial period which contrasts with a previous study in the Waikato (O'Connor et al. 1989) where a $40-100 \%$ fluctuation in pasture Na status occurred over a 7-month period. Previous surveys (Joyce \& Brunswick 1975; Smith \& Middleton 1978) have highlighted the incidence of low Na status pastures on many North and South Island soils including pumice soils and this situation continues to exist. Low $\mathrm{Na}$ status pastures continue to emerge in routine pasture analyses on the Central Plateau pumice soils, the Waikato, and in many other dairying areas, particularly on inland properties. Overall it would appear that pasture sampling is the easiest and most reliable means of diagnosing $\mathrm{Na}$ deficiency.

\section{Other sources of sodium}

The water supply is an obvious source of sodium. On the trial property the water supply contained $9.1 \mathrm{mg} /$ $\mathrm{kg}$. This would mean a cow drinking 30 litres/day would consume $0.27 \mathrm{~g}$ of $\mathrm{Na} /$ day. This is a negligible portion of the $14 \mathrm{~g} \mathrm{Na} /$ day (or $35 \mathrm{~g}$ salt) drenched to the animals in the trial so that water intake of $\mathrm{Na}$ was not a confounding factor in the trial. Animals can also obtain Na from ingestion of soil (Towers \& Smith 1983) but this was not obvious in the trial.

\section{Economics of salt supplementation}

Using the current trial response of $12.8 \%$ in milk production, a cow producing an average $280 \mathrm{~kg} \mathrm{MS/}$ lactation would produce an additional $35.8 \mathrm{~kg}$ MS. At $\$ 3.60 / \mathrm{kg}$ MS (final payout) this would mean an additional \$128.90/cow income. The additional costs entail $35 \mathrm{~g}$ salt/cow $/ 270$ day lactation (a total of $9.45 \mathrm{~kg}$ salt/cow) at $\$ 0.30 / \mathrm{kg}$ or $\$ 2.84 /$ cow plus any additional labour costs associated with drenching or administrating salt.

\section{Methods of salt supplementation}

It is apparent from the current trial result that where $\mathrm{Na}$ deficiency is identified, it is important to ensure that all animals receive their correct daily $\mathrm{Na}$ supplement. The benefits in increased returns far outweigh the cost of the salt.

Drenching is considered the most effective method of supplementation (although the current experiment did not test this assertion). The dosing regime should aim to provide the daily $\mathrm{Na}$ requirement ignoring any contribution from the pasture. Towers \& Smith (1983) suggested a cow producing 20 litres milk/day will require $15 \mathrm{~g} \mathrm{Na}$ /day whereas a cow producing 30 litres milk/ day will require $21 \mathrm{~g} \mathrm{Na}$ /day. This compares with the requirement for maintaining liveweight at $3 \mathrm{~g} \mathrm{Na} /$ day. 
There is still some concern about mixing and drenching salt and bloat materials together but the reasons for this concern are unclear. A trial is currently underway to resolve this question. Direct intake of salt mixed with meal is also considered a satisfactory method of supplementation.

Water treatment and blocks/licks are other methods of supplementation but are less effective as animal intakes will vary within the herd. Again, work needs to be done on the importance of giving animals the correct rate of salt supplementation. Indications from the current trial suggest that milk production from the farmer's cows given $7 \mathrm{~g} \mathrm{Na}$ /day (as against $14 \mathrm{~g}$ in the trial animals) was about half that of the treated trial animals.

Salt applied as a fertiliser to pasture is another effective way of increasing the pasture $\mathrm{Na}$ status of natrophilic pastures like ryegrass/clover but is not effective on natrophobic pastures like lucerne and kikuyu (Smith et al. 1983). Salt would need to be applied annually to maintain the pasture Na status. An effective maintenance rate is considered to be $40 \mathrm{~kg}$ $\mathrm{Na}$ (100 kg salt)/ha/annum (O'Connor et al. 1989).

\section{Concerns with salt supplementation}

Salt can be toxic to animals when given in excess. Toxic animals display a nervous disposition (B. Smith, AgResearch, pers. comm.). It is important to ensure that an adequate water supply is always available.

There have been concerns raised with topdressing salt to pastures already high in $\mathrm{K}$ and marginal in $\mathrm{Mg}$ (Smith et al. 1983). Blood Mg levels have been shown to be lowered in animals grazing such pastures but provided good $\mathrm{Mg}$ supplementation is practised this should not be a problem.

\section{Conclusions}

A $12.8 \%$ milk production response to salt supplementation was obtained in this trial at Waikite near Rotorua. The result was obtained on pastures averaging $0.05 \% \mathrm{Na}$ and hence the response could be considered the best one could expect. As pasture Na status increases a lower response could be expected. Further work is required to confirm the upper limit of response.

The response was in increased milk yield with no effect on fat or protein content. There was an indication from the results that the higher-producing cows responded better than the lower-producing animals. Indications are that sodium deficiency is likely to become more prevalent on dairy farms in the future and that there are likely to be good economic benefits to using salt where deficiencies occur.

Further research is required to determine the critical $\mathrm{Na}$ pasture levels for production responses, methods of supplementing salt, rates of salt application to pasture and how well salt dissolves and mixes with other drenches.

\section{ACKNOWLEDGEMENTS}

To Jim and Beverley Rotherham, and Karl Johnson for their co-operation in the running of the trial. Also to Robin Hopkirk of Animal Health Services, Rotorua, Livestock Improvement Corporation, Newstead, Animal Health Laboratory Ruakura and the Soil Fertility Service, Ruakura.

\section{REFERENCES}

Chiy, C.P.; Phillips, C.J.C. 1991. The effect of sodium chloride application to pastures, or its direct supplementation, on dairy cow production and grazing preference. Grass and Forage Science 46: 325-331.

Chiy, C.P.; Phillips, C.J.C. 1995. Sodium in ruminant nutrition, production, reproduction and health. pp. 107-114. In: Sodium in Agriculture. Eds. Phillips, C.J.C.; Chiy, P.C. Chalcombe Publications, Canterbury.

Joyce, J.P.; Brunswick, L.C.F. 1975. Sodium supplementation of sheep and cattle fed lucerne. New Zealand Journal of Experimental Agriculture 3: 299-304.

Morton, J.D.; Smith, L.C.; Roberts, A.H.C.; O'Connor, M.B.; Hunt, B.J. 2000. Effect of $\mathrm{K}$ and $\mathrm{N}$ on minerals required by dairy cows. In: Soil Research: A knowledge industry for land-based exporters. Eds. Currie L.D.; Loganathan P. Occasional Report No. 13. Fertiliser and Lime Research Centre, Massey University, Palmerston North. (In press).

National Research Council. 1989. Nutrient requirements of dairy cows. $7^{\text {th }}$ Edition. National Academy Press, Washington DC.

O'Connor, M.B.; Addison, B.; Miller, A.D. 1989. The effects of topdressing pastures in the Waikato with sodium chloride. Proceedings of the New Zealand Grassland Association 50: 83-87.

Rajendram, G.S.; Ledgard, S.F.; Monaghan, R.; Penno, J.W.; Sprosen, M.; Ouyang, L. 1998. Effect of rate of nitrogen fertiliser on cation and anion leaching under intensively grazed dairy pasture. pp. 67-74. In: Long-term nutrient needs for New Zealand's primary industries: global supply, production requirements and environmental constraints. Eds. Currie L.D; Loganathan P. Occasional Report No. 11. Fertiliser and Lime Research Centre, Massey University, Palmerston North.

Smith, G.S.; Middleton, K.R. 1978. Sodium and potassium content of topdressed pastures in New 
Zealand in relation to plant and animal nutrition. New Zealand Journal of Experimental Agriculture 6: 217-225.

Smith, G.S.; Young, P.W.; O'Connor, M.B. 1983. Some effects of topdressing pasture with sodium chloride on plant and animal nutrition. Proceedings of the New Zealand Grassland Association 44: 179-185.

Towers, N.R. 1983. Changes in the salivary sodium: potassium ratio in lactating cows in response to changes in sodium intake. Proceedings of the New Zealand Society of Animal Production 43: 131133.

Towers, N.R.; Smith, G.S. 1983. Sodium (Na). pp. 115-124. In: The mineral requirements of grazing ruminants. Ed. Grace, N.D. New Zealand Society of Animal Production Occasional Publication No.9. 
